\title{
装配式建筑工程管理的影响因素与对策研究
}

安卫龙

河北高科项目管理有限公司，河北 石家庄 050000

[摘要] 装配式建筑作为一种新型工程模式受到建筑领域的高度重视, 具有施工速度快、质量高的优势, 但实际发展却受到多 种因素限制。文章从配件管理、管理制度、合作模式的角度分析影响装配式建筑工程管理的因素，并提出相应的解决措施， 希望能够为装配式建筑工程的发展提供帮助。

[关键词]装配式建筑; 工程管理; 影响因素

DOI：10.33142/ec.v3i12.2964 中图分类号：TU71 文献标识码：A

\section{Study on Influencing Factors and Countermeasures of Prefabricated Construction Project Management}

AN Weilong

Hebei Gaoke Project Management Co., Ltd., Shijiazhuang, Hebei, 050000, China

\begin{abstract}
As a new engineering mode, prefabricated building is highly valued in the construction field, with the advantages of fast construction speed and high quality, but its actual development is limited by many factors. This paper analyzes the influencing factors of prefabricated construction engineering management from the perspective of accessories management, management system and cooperation mode and puts forward corresponding solutions, hoping to provide help for the development of prefabricated construction engineering.
\end{abstract}

Keywords: prefabricated building; project management; influencing factors

\section{引言}

装配式建筑工程是指提前在工厂预制建筑施工中所需要的部件并完成装配后，运送到施工现场进行安装。能够保 证建筑工程的整体质量, 缩短建筑工期、降低成本投入, 在节能环保方面也有一定优势。为此, 建筑企业应加强对装 配式建筑工程的重视程度，确保施工中各工序的有效衔接，为企业发展提供新方向。

\section{1 影响装配式建筑工程管理的因素}

\section{1 配件管理不标准}

预制构配件的质量会直接影响装配式建筑工程的施工质量，应作为重点检查内容进行管理。目前，预制构配件管 理制度表面化现象严重, 对于质量的验收多停留于表面是否存在严重的缺损和变形, 并没有结合施工图纸对照其制作 型号、尺寸是否符合要求, 无法保证预制构配件的精准度, 增加装配式建筑工程施工中存在的安装误差。同时, 预制 构配件的工厂通常距离装配式建筑工程施工现场很远, 在需要配备专门车辆进行运输, 如果在装车过程中没有做好预 制构配件的保护, 很容易会在运输中造成破损, 影响装配式建筑工程的施工质量和施工进度。当预制构配件运入到施 工现场后，缺少专业人员对其排放进行合理规划，增加施工现场人为因素和自然因素对预制构配件的影响。

\section{2 传统管理制度落后}

装配式建筑工程顺利施工需要完善管理制度的支持, 在施工过程规范现场人员行为, 明确各参建单位责任, 保证 施工质量。但实际上, 装配式建筑工程管理制度存在缺陷, 管理人员的职业素养不足之处支撑管理体系的充分发挥, 装配式建筑工程施工质量安全问题得不到有效落实, 施工人员的生命安全难以保障, 无法实现对施工现场材料、机械 设备、人员操作规范等方面的全面细致监管, 经常会出现装配式建筑工程部分施工质量不达标而返工的情况, 甚至存 在安全隐患威胁施工人员的生命安全。

\section{3 施工单位合作效果差}

装配式建筑工程项目涉及参建方较多, 如设计单位、预制构配件工厂、施工单位、业主、监理单位等, 各参建单 位在施工中所负责的内容各不相同却存在必然联系，只有多方合作才能保证装配式建筑工程项目的施工质量。但是， 现阶段装配式建筑工程项目施工中，各参建单位缺乏沟通交流，“各自为政” 的情况较为常见，没有交换和共享施工、 设计、作业中产生的数据信息, 降低各种资源的利用率, 无法为装配式建筑工程设计方案的可行性提供有效保障, 施 工现场经常处于混乱的状态下。 


\section{2 强化装配式建筑工程管理的措施}

\section{1 预制构配件的全过程管理}

装配式建筑工程主要是对大量预制构配件的重新安装, 其质量会直接影响到建筑物整体功能的发挥, 需要对其预 制的全过程进行跟踪管理, 避免影响建筑物性能。第一, 加强预制构配件设计阶段的管理, 利用 BIM 技术构建建筑模 型, 明确装配式建筑工程项目中需要使用的构配件, 确保建筑整体架构、内部结构、给排水设计、暖通空调和电气设 备安装、消防设施配备的完整性, 为装配式建筑工程质量提供有效保障。同时, 施工企业应利用现代化科学技术进行 装配式建筑施工图纸的绘制, 准确标注构配件节点、吊点、预留预埋、外轮廓等关键部位, 并针对施工进度对不同构 配件进行编号, 在安装过程中按照编号对应安装, 不仅能够保证施工质量, 确保装配式建筑工程安装的合理性, 还能 够为施工人员提供便利, 降低误操作率 ${ }^{[1]}$ 。

注重预制构配件的现场运输管理, 从构配件预制工厂到装配式建筑工程施工现场的途中，可能会存在各种各样的 安全隐患, 为保证构配件质量, 需要在装车前做好其防护工作, 避免运输途中造成破损。当运输到施工现场时, 要注 意构配件下车环节, 避免在移动过程中与其他材料发生碰撞, 影响构配件结构质量, 还可能会造成施工现场的混乱。 第三, 深化对装配式建筑工程施工现场的监督与管理, 当预制构配件运送到施工现场, 不应直接进行安装, 而是要先 对其型号、外观、尺寸、质量等方面进行检查, 对照施工设计图纸逐一分析, 确保满足装配式建筑工程设计要求后, 才能投入施工。同时, 在安装预制构配件时, 需要严格依照设计图纸进行装配, 在完成部分安装后, 应校对其安装精 准度, 尽可能降低安装偏差, 避免在后期组装的过程中因误差过大而无法有效安装, 影响装配式建筑工程施工质量。

\section{2 工程管控制度的完善}

我国装配式建筑工程管理制度与发达国家相比存在缺陷, 具有继续进步的空间, 建筑企业应重点关注。首先, 建 筑企业在构建装配式建筑工程管理制度时, 应与我国基本国情和建筑领域的发展情况相结合, 主动借鉴发达国家在管 理上存在的优势, 取其精华去其糟粕, 借助现代化科学技术创新相关人员的管理理念, 篮选装配式建筑工程档案资料, 并对施工全过程开展经验归纳总结, 确保工程管理制度能够对施工各个阶段进行准确而细致的监管, 保证装配式建筑 工程的施工质量。其次, 建筑企业应顺应信息时代的发展, 结合互联网技术、大数据技术、计算机技术等完善装配式 建筑工程管理系统, 运用科学系统准确计算施工进度变化和施工质量变动, 并利用数据结果调整施工方案, 及时规避 现场施工中可能会发生的问题, 并有针对性的加强管理力度。最后, 应从人员的角度完善工程管控制度, 重视对施工 人员的监督和约束, 建立激励机制、奖惩制度、岗位责任制等制度规范施工人员行为, 确保装配式建筑工程施工中如 果出现问题, 能够及时找到第一责任人, 避免危害的进一步扩大。同时, 适当的奖惩机制能够激发施工人员的工作积 极性, 以认真严谨的态度完成装配式建筑工程中预制构配件的安装, 在施工现场中形成互相监督的氛围, 唤醒施工人 员的安全意识，保证其生命财产安全。

\section{3 深化各单位的协同管理}

目前, 我国建筑领域正大力推广 “合作共赢” 理念, 通过装配式建筑工程施工过程中各个参建部门的协同合作, 创造更高的经济效益和社会价值。在实际施工中, 装配式建筑工程涉及到的环节众多, 并且不同阶段都由相应部门负 责, 如果各参建单位之间不及时沟通, 很容易出现施工重复、施工环节缺失、责任分配不明确的问题, 无法保证装配 式建筑工程的质量。为此, 建筑企业应充分发挥自己的领导作用, 在施工现场对各参建单位进行有效协调, 结合完善 的施工现场管理制度明确注意事项, 并给以书面形式下发到各个单位部门, 要求各单位是施工中严格执行条例, 实现 自上而下的装配式建筑工程施工现场规范化管理 ${ }^{[2]}$ 。另外, 为确保装配式建筑工程各参建单位的协同合作效率, 应借助 现代化技术创新管理方式。例如, 利用二维码扫描技术管理运入到施工现场的预制构配件, 确保 “一件一码”, 有效促 进各参建单位的协调配合，避免管理过程中发生混乱，进而拖慢装配式建筑工程的施工进度，影响工程质量。

\section{3 结束语}

综上所述, 装配式建筑工程在实际应用中会受到多种因素的影响, 为保证其施工的系统性和综合型, 建筑企业应 深化自身对装配式建筑的了解, 更新施工人员的专业素养, 借助信息技术构建完善的管理体系, 通过各个参建单位的 密切配合, 实现经济效益的全面提升。

\section{[参考文献]}

[1]代悟.装配式建筑工程管理的影响因素及应对措施 [J].居舍, 2020(23): 141-142.

[2]李继宁. 装配式建筑工程管理的影响因素与对策 [J].工程技术研究, 2020(15) : 161-162.

作者简介: 安卫龙（1987.9-) 男，毕业院校：石家庄铁道大学；现就职单位：河北高科项目管理有限公司。 